\title{
Az idősek szociális kapcsolatai és szabadidő-eltöltése
}

\section{R. FEDOR ANITA ${ }^{1}$ - UNGVÁRI SÁNDOR² - MARKOS VALÉRIA ${ }^{3}$}

\begin{abstract}
ABSZTRAKT
A társadalmak idősödésének jelensége mára már közismertté vált, a világ számos országában érzékelteti demográfiai, gazdasági, társadalmi hatását. A születéskor várható átlagos élettartam növekedése, az alacsony gyermekszám magától értetődő módon hívta életre a csökkenő, elöregedő társadalmak megjelenésének folyamatát. Mindez számos feladat elé állította a szakpolitikák, a hazai és nemzetközi szervezetek képviselőit, elsősorban az aktív, egészséges időskor elösegítése érdekében. Tanulmányunkban egy 167 fös empirikus vizsgálat eredményeinek egy részét mutatjuk be, melyet a Szent Lukács Görögkatolikus Szeretetszolgálattal közösen bonyolítottunk le 2019 telén azzal a céllal, hogy felmérjük az idősek helyzetét, szükségleteit. Jelen írásunkban azon eredményeit ismertetjük, melyek a közösségi tevékenységekre, a szabadidő eltöltésére, valamint a szociális kapcsolatok jellemzőire koncentrálnak. Elemző munkánk során azt tapasztaltuk, hogy az érintettek, a bentlakásos idősek otthonában élők, fokozottan nyitottak a fizikai és mentális aktivitás megőrzését szolgáló közösségi tevékenységekre, melyek hosszútávon esélyt biztosítanak jóllétük fenntartásához, javításához.
\end{abstract}

KULCSSZAVAK: idősödő társadalom, szükségletfelmérés, szociális kapcsolatok, közösségi tevékenységek, szabadidő, mentális egészség

\section{ABSTRACT}

\section{Social contacts and spending of leisure time of the elderly}

The phenomenon of the aging of societies is now well-known, demonstrating its demographic, economic and social impact in many countries around the world. The increase in average life expectancy at birth and the low number of children have naturally triggered the emergence of declining, aging societies. All this has led to a number of tasks for policy makers, domestic and international organizations, primarily to promote active, healthy aging. This article describes some of the results of an empirical study of 167 people conducted jointly with St. Luke's Greek Catholic Charity in the winter of 2019 in order to assess the situation and needs of the elderly. This article presents the results of our study, which focuses on community activities, leisure, and

\footnotetext{
${ }^{1}$ Debreceni Egyetem Egészségügyi Kar, e-mail: fedor.anita@foh.unideb.hu

${ }^{2}$ Szent Lukács Görögkatolikus Szeretetszolgálat, e-mail: ungvari.sandor@szlgsz.hu

${ }^{3}$ Debreceni Egyetem Nevelés- és Művelődéstudományi Doktori Program, e-mail: markosvaleria.90@gmail.com
} 


\section{TANULMÁNY}

social relationships. During our analytical work, we found that those living in residential care homes are more open to community-based activities to maintain physical and mental activity

KEYWORDS: aging society, needs assessment, social relations, community activities, leisure, mental health

\section{Bevezetés}

Az idősödés folyamatának világméretűvé válása, az öregedő társadalmak egyre bővülő trendje komoly feladat elé állítja a demográfusokat, a szociális szakembereket és minden, a témával foglalkozó kutatót. A WHO előrejelzése szerint a 60 éves és annál időseb korosztály népességen belüli arányának emelkedése tovább folytatódik, várhatóan 2050-re a jelenlegi 60 évnél idősebb népesség száma kétszeresére nő. Magyarországon a 65 éves és ennél idősebb népesség aránya 1990 és 2017 között 13\%-ról 19\%-ra növekedett, és az előrejelzések szerint 2070-re eléri a 29\%-ot (Monostor - Gresits 2018: 127).

Az aktív idősödés iránti igény innovatív szolgáltatástervezési folyamat felé indította el a gyakorlatban dolgozó szakemberek gondolkodását. Az idősek életminőségének javítása, jóllétének megtartása, emelése, a fizikai aktivitás megőrzése mellett a mentálisan aktív életmódot is magába foglalja. A fizikai és mentális egészség megőrzése az öregedő társadalmak központi kérdésévé vált mind az otthonukban élő, mind pedig a bentlakásos intézmények idős lakói számára. Tanulmányunkban három észak-alföldi bentlakásos idősotthonban lebonyolított vizsgálatunk azon eredményeit ismertetjük, melyek a közösségi tevékenységekre, a szabadidő eltöltésére, valamint a szociális kapcsolatok jellemzőire koncentrálnak.

\section{Idősödő társadalom}

Életünk talán egyik legkritikusabb életszakasza az öregkor. Az életkor előrehaladtával az egyén lehetőségei folyamatosan szűkülnek. Ez a folyamat magában rejti a szerepek feladásának, megváltoztatásának kényszerét (Donászy 2002). Az idősödés folyamata együtt jár a gazdasági inaktivitással, a munka világából való kikerüléssel, melynek közvetlen velejárója a társas kapcsolatok leépülése. Preston (1994) az időskort kritikus fejlődési periódusként definiálja, melyet meghatározó biológiai, fizikai, mentális, pszichoszociális és társadalmi változások kísérnek. Ezen változásokhoz való alkalmazkodás sikerességét az öregségre történő felnőttkori felkészülés határozza meg, melyet alapvetően társadalmi-kulturális hatások formálnak (Bagdy 2000, Jeszenszky 2003, Pikó 2007). A nyugati társadalmak teljesítményközpontúak, a teljesítmény értékelése pedig leginkább a fizetett munkavégzéshez, az aktivitáshoz kötődik (Hézser 2002). Ebből adódóan az idősödő, nyugdíjba vonuló személy egy idő után feleslegesnek, a társadalom haszontalan tagjának érezheti magát. Ezt az 


\section{TANULMÁNY}

állapotot tompíthatja a megsokszorozódott szabadidő előre megtervezett, hasznos eltöltése. A munka és magánélet konfliktusával számoló fiatalabb generációk segítése, az unokákkal való törődés szintén lehetőséget biztosít arra, hogy visszakapcsolja az idősek csoportját a társadalom vérkeringésébe. Néhány akadályozó tényezőt mégsem hagyhatunk figyelmen kívül: ilyen például a gyerekektől, unokáktól való fizikai távolság, vagy az a jelenleg és már egy ideje uralkodó demográfiai trend, mely szerint a fiatal (0-14 éves) korosztály aránya folyamatosan csökken, és ezzel párhuzamosan a 60 évesek és annál idősebbek száma drasztikusan emelkedik. Ez azt is jelenti, hogy az időskorba kerülőknek egyre kevesebb gyermeke és unokája van, egyre kevesebb velük hasonló korú testvérrel és unokatestvérrel rendelkeznek, ami együtt jár az elsődleges, családon belüli támogatórendszer diszfunkciójával (Iván 2002). Ez is jól mutatja, hogy az idősödő társadalomban a generációk közötti megoszlás jelentősen átalakult. Az öregedési index a népesség idősödésének illusztrálására használt mérőszám, mely a 14 éves és ennél fiatalabb népességre jutó idősek (65 évesek és annál idősebbek) arányát mutatja. Az 1. ábra adatai ennek a mutatónak a területi és időbeli alakulását mutatja. Látható, hogy 18 év távlatában jelentősen nőtt az öregedési index. Országos átlagban ma Magyarországon 100 fő 14 év alatti gyerekre 133 fő 65 éves és idősebb ember jut. Ez az arány vizsgálatunk helyszínén, az Észak-alföldi régióban a legkedvezőbb, bár az idős generáció száma itt is meghaladja a fiatalokét. A legrosszabb helyzetben a dél-dunántúli desztináció van, ahol az idősek száma másfélszer annyi, mint a 14 éves és annál fiatalabbaké.

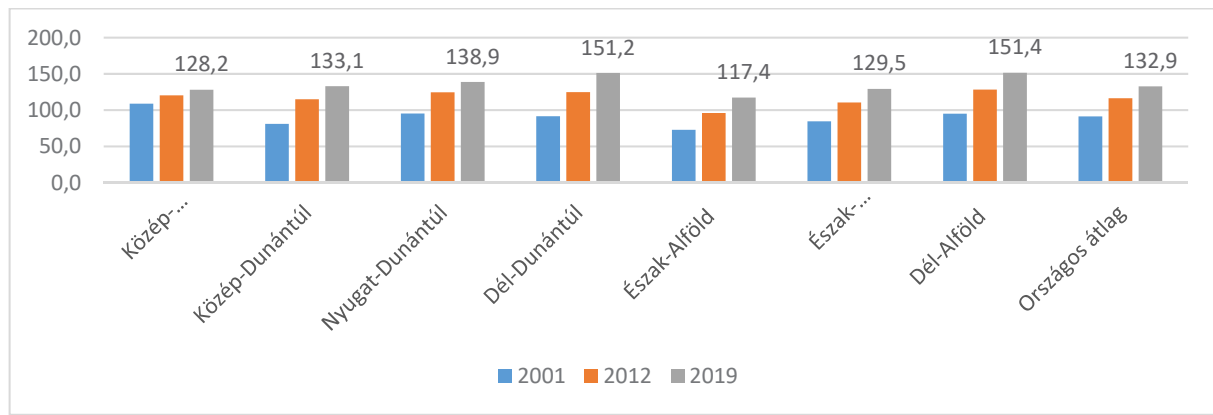

1. ábra. Öregedési index

Forrás: Saját szerkesztés

Egészségszociológiai szempontból azt mondhatjuk, hogy az idősödés folyamatában számos, korábban védőfaktorként funkcionáló tényező leépül, mely hosszú távon negatívan befolyásolja az időskor megélését. A társas kapcsolatok beszűkülése, a házastárs elvesztése elmagányosodáshoz vezethet, a gazdasági inaktivitás az addig megszokott életszínvonal mérséklődését vonhatja maga után. A veszteségélmények halmozódása stresszhelyzetet generál, mely hosszútávon egészségkárosító lehet. 


\section{TANULMÁNY}

A krízishelyzet feloldásában, egy örömteli időskor elérésében meghatározó szerepe van a támogató családi háttérnek. Az utóbbi évtizedekben azonban a családi szerkezetek és a nemi szerepek átalakulása figyelhető meg társadalmunkban, melynek hatásai az idősgondozásban is érzékelhetőek (Szalkóné 2020). Ezzel összefüggésben egyre nagyobb szerepe van az idősek életminőségének alakításában, megőrzésében az időseket gondozó intézményeknek, melyek szolgáltatásainak folyamatos felülvizsgálatával, fejlesztésével sokat tehetnek az idősekért.

\section{Elméleti háttér}

A társas támogató rendszer hiánya szorosan összefügg a vélt, s hosszú távon a valós egészségi állapottal. Azok, akiknek a társas kapcsolataik beszúkülnek, nagyobb eséllyel válnak szomorúvá, produkálnak depresszív tüneteket, számolnak be a feleslegesség érzéséről, mindez pedig meghatározza általános közérzetüket, elégedettségüket. Ezek a jellemzők az idős korosztálynál fokozottabban jelentkeznek, ezért a társas szabadidő-eltöltésüket egyfajta védőfaktorként foghatjuk fel. Ez kiemelten érinti a bentlakásos idősek intézményének lakóit, akik gyakran valamilyen nehezített életkörülmény, betegség vagy haláleset miatt döntenek az idősek otthona mellett. A változás mindig alkalmazkodással, az új környezet megismerésével, az ott élőkkel való kapcsolatfelvétellel jár, mely sokszor nem egyszerű feladat. Azonban a tapasztalatok azt mutatják, a sokszor elszigetelten élő idősek számára a bentlakásos intézmények a közösségi hálózatok bővülését, új társas kapcsolatok kialakulását, új, akár addig ismeretlen szabadidős tevékenységek kipróbálásának a lehetőségét rejtik magukban. Mind a hazai, mind a külföldi vizsgálatok megerősítik azt a régóta érvényes megállapítást, hogy a beszúkült emberi kapcsolatok, az aktívan eltöltött napok alacsony száma, a társas támogatórendszer hiánya negatív hatással bírnak az egyének mentális és fizikai jóllétére, egészségi állapotára (Berkman - Syme 1979, Ellwardt et al. 2014, Kopp - Skrabski 2007). Ellwardt et al. (2014) hozzáteszi, hogy az időskori jövedelmi szegénység csökkenti a szoros kapcsolatok ápolásának, kialakulásának a valószínűségét.

Cohen-Mansfield et al. (2012) a társas kapcsolatok mellett a szabadidős tevékenységet azonosították a feleslegesség érzése elkerülésére, s ezt a stresszel szembeni védőfaktorként is említik. Janke, Nimrod és Kleiber (2008) a negatív életesemények leküzdésében tulajdonított jelentős szerepet a szabadidős aktivitásnak.

A hazai szakirodalom szintén amellett érvel, hogy az idősek szociális kapcsolatainak jellemzői, ezek minősége szorosan kapcsolódik a szabadidő eltöltésének jellemzőihez, s ez különösen igaz a bentlakásos intézményekben élőkre. Korábbi vizsgálatok eredményei szerint az idősek a szabadidejüket szívesen töltik társaságban, például a vallásgyakorlás területén, de a szervezeti tevékenységekben való közremúködésük is kiemelkedő (Törőcsik 2015). Mindemellett szeretnek egymással 


\section{TANULMÁNY}

beszélgetni és tévét nézni. Az idősek a tévénézésre naponta másfélszer annyi időt fordítanak, mint a teljes lakosság (Lampek 2015).

Mindezek alapján megállapíthatjuk, hogy a szervezett szabadidős programok tervezésének kedvez az intézményi környezet, hiszen a célcsoport mindamellett, hogy fizikailag helyben van, javaslataikkal, ötleteikkel - érdeklődésüknek megfelelően - alakíthatják a programok tartalmát. Ezt a megállapítást erősíti közvetve Huszti - Ember (2019) szerzőpáros eredménye, akik a telepi körülmények között élők társas kapcsolatait vizsgálva arra jutottak, hogy a nagyobb lakótelepen élők beszükültebb kapcsolatrendszerrel bírnak.

\section{A kutatás célja és módszerei}

2019 telén kutatást indítottunk az Észak-alföldi régióban működő három idősek gondozását ellátó intézményében, azzal a céllal, hogy felmérjük a támogatási és beavatkozási szükségleteket annak érdekében, hogy a biztonságos és magas színvonalú szolgáltatástervezés alappilléreit még inkább megerősítse a fenntartó. A bentlakásos intézményekben demens és pszichiátriai ellátás is folyik.

Ehhez kapcsolódóan felmértük a bentlakásos idősek otthonában élők szociális kapcsolatait, valamint hozzátartozóikhoz, lakótársaikhoz és az intézmény dolgozóihoz való viszonyait. Kérdéseket tettünk fel az egészségmagatartással kapcsolatos ismeretekről, a szabadidő eltöltéséről. Vizsgáltuk a lakókörülményekkel való elégedettséget, és végül arra kértük a válaszadóinkat, hogy fogalmazzanak meg javaslatokat a szabadidő hasznos eltöltésére, az időskori tanulást, informálódást segítő témák tartalmára és a lakókörülmények javítására. Azt várjuk, hogy az ily módon kidolgozásra kerülő, az idősek szükségleteire reflektáló szolgáltatásfejlesztés hatással lesz az érintettek általános közérzetére, mentális aktivitására és életminőségére. További célunk egy olyan megalapozó tanulmány elkészítése volt, mely hosszú távon segítséget nyújt az aktív és egészséges időskort, valamint az élethosszig tartó tanulást biztosító szolgáltatások kialakítására. Írásunkban az idősek szociális kapcsolatainak, szabadidő-eltöltésének, tanulást biztosító szolgáltatások elemzésének és az ezekre vonatkozó javaslatainak bemutatására kerül sor.

\section{MINTA ÉS MÓDSZER}

Vizsgálatunk alanyait az Észak-alföldi régióban működő három egyházi fenntartású intézmény ellátotti köre alkotta. A szeretetszolgálat mind az alap, mind pedig a szakosított ellátás területén jelen van. Ehhez kapcsolódóan megtörtént a házi segítségnyújtás klienseinek (200 fô) és a bentlakásos idősek otthonában élők (167 fő) helyzetének elemzése, szükségleteinek felmérése. Jelen tanulmányunkban azonban csak a bentlakásos intézmények lakóinak eredményeit mutatjuk be. 


\section{TANULMÁNY}

A felmérésbe bekerült két intézményben jelenleg 232 és 94 fő lakik. Az ellátottak között vannak demens személyek és pszichiátriai betegek, ezért első lépcsőben az intézményvezetőkkel egyeztetve szakértői mintavétellel dolgoztunk (ezt a két csoportot nem emeltük be a vizsgálatba), majd ezt követően teljes körű lekérdezést terveztünk. A vizsgálatban való részvétel önkéntes volt, így a demens és pszichiátriai betegek, valamint a felmérésben részt venni nem kívánók nélkül összesen 167 fő válaszolt a kérdőív kérdéseire. Ez a lakók 51\%-a, akik körében kérdezőbiztosok bevonásával személyes lekérdezésen alapuló kérdőíves adatgyűjtést alkalmaztunk. Az adatok rögzítését és feldolgozását SPSS 25.00 Windows szoftver segítségével végeztük. A minta általános jellemzőin túl a társas támogató környezet és a szabadidő-eltöltés mellett az idősek közösségi tevékenységére vonatkozó elvárásokat mutatjuk be.

\section{A VIZSGÁLAT DIMENZIÓI}

A kérdőívek kérdéseire a mintába beválasztott valamennyi lakó, összesen 167 fő válaszolt. A kérdőív három fő részből állt. Először megkérdeztük az időseket arról, hogy hogyan érzik magukat a bentlakásos intézményben, illetve arról, hogy mitől éreznék jobban magukat, mi segítené az aktív és egészséges időskorukat, mi támogathatná a hasznos szabadidő-eltöltésüket, van-e igényük és lehetőségük új ismeretek megszerzésére. A második részben az idősek egészség-magatartásával kapcsolatban tettünk fel kérdéseket. Végül a kérdőív záró részében került sor a biográfiára. Az eredmények bemutatását a szociodemográfiai, szociokulturális jellemzők bemutatásával kezdjük, majd az idősek szociális kapcsolataira, szabadidő-eltöltésére, ismeretszerzésre vonatkozó motivációikra fókuszálunk.

\section{Az idősek általános jellemzői}

A bentlakásos intézmények válaszadóinak nemek szerinti megoszlásában visszatükröződik az országos trend, mely szerint az intézményi körülmények között élő idősek körében több a nő, mint a férfi. Ez a jelenség a hazai demográfiai sajátosságok leképeződése is egyben, mivel Magyarországon a férfiak és nők születéskor várható átlagos élettartama jelentősen eltér egymástól, a nők javára. 2018-ban 5,2 év volt a különbség (KSH - Népesség, népmozgalom [1941-]).

A válaszadóink 68,7\%-a nő és 31,3\%-a férfi. Többségük (57,9\%) a 60-79 évesek csoportjához tartozik, 3 fő 50 éves kor alatti. Az idősotthoni lakók 7,9\%-a (13 fô) 48-59 éves, 26,8\%-a 60-69 éves, 31,1\%-a 70-79 éves, 28,7\%-a pedig 80 és 89 éves kor között van. 9 fő válaszadó 90 éves vagy e feletti. A lakók átlagos életkora 74 év.

Az idősek iskolai végzettség szerinti megoszlása alapján megállapíthatjuk, hogy a lakók 15,3\%-a (25 fő) kevesebb, mint nyolc osztállyal, 34,4\%-a (56 fó) nyolc osztállyal rendelkezik. A megkérdezett idősek 30,7\%-ának (50 főnek) van szakiskolai 


\section{TANULMÁNY}

szakképesítése, 10,4\%-nak (17 főnek) van érettségije. 6,2\% (10 fő) főiskolai, 3,1\% (5 fő) egyetemi diplomával rendelkezik (2.ábra).

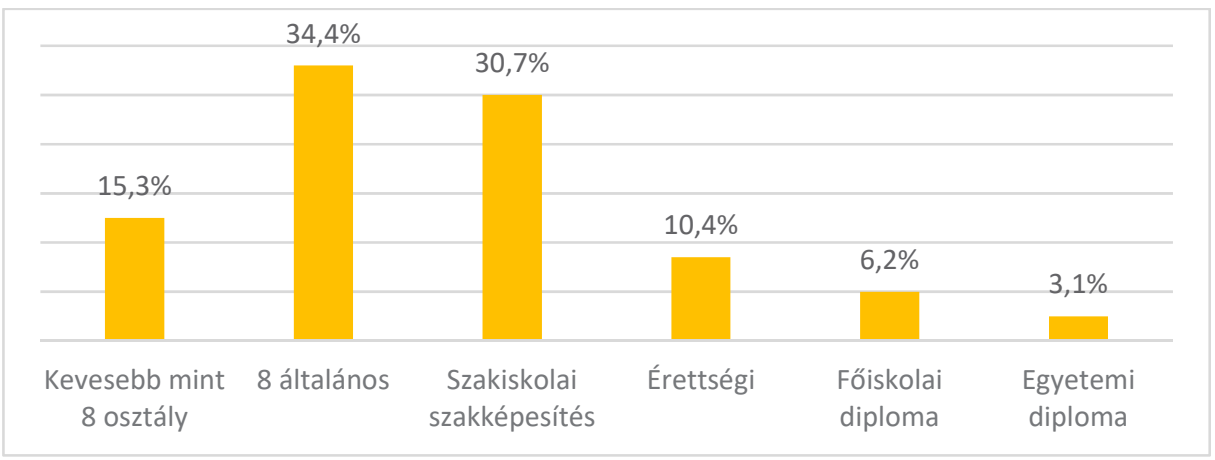

2. ábra. A válaszadó idősek iskolai végzettség szerinti megoszlása (\%) Forrás: Saját szerkesztés

A válaszadó időseknek több mint a fele özvegy 51,5\%, (85 fő). 18,8\% (31 fő) házas, 18,8\% (31 fô) pedig elvált, míg 3 fő (1,8\%) azt válaszolta, hogy az élettársával él. Nőtlen, hajadon családi állapotról a válaszadók 9,1\%-a (15 fő) nyilatkozott (3. ábra).

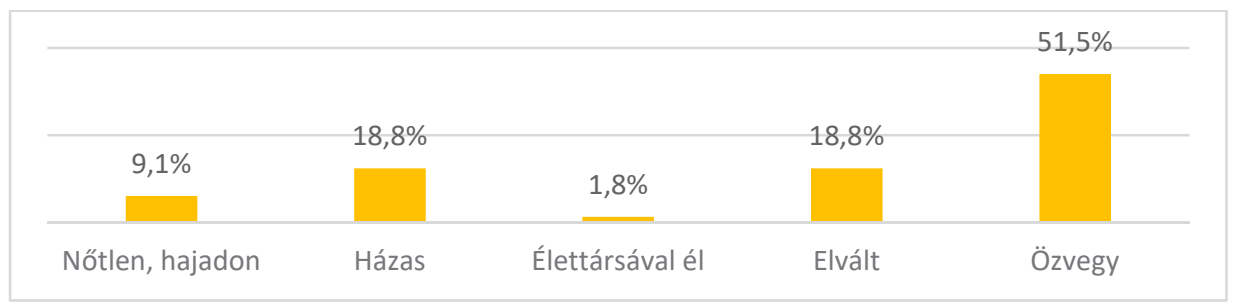

3. ábra. A válaszadó idősek családi állapot szerinti megoszlása (\%) Forrás: Saját szerkesztés

Az idősek 80\%-a (128 fö) válaszolta azt, hogy van gyermeke, és 20\%-a (32 fő) azt, hogy nincs neki. Közel egyharmaduknak (38 főnek) egy gyermeke van, 40\%-ának (50 főnek) két gyermeke, 18,4\%-ának (23 főnek) három gyermeke, 8,8\%-ának (11 főnek) pedig négy gyermeke van. További 0,8\%-nak (egy-egy idős válaszadónak) van öt, hat, illetve hét gyermeke (4. ábra). Az idős lakók közül 104 fő tartja a kapcsolatot a gyermekével/gyermekeivel, azaz akinek van gyermeke, azoknak a 81,9\%-a ápolja is vele a kapcsolatot. 18,1\% (23 fő) pedig azt válaszolta, hogy van gyermeke, de évek óta nincs köztük kapcsolatfelvétel. 


\section{TANULMÁNY}

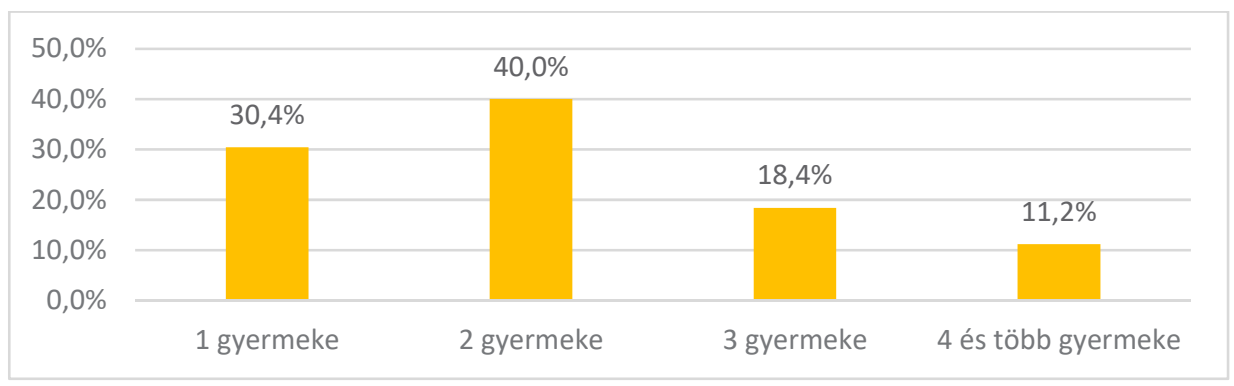

4. ábra. A válaszadó idősek gyermekeik száma szerinti megoszlása (\%)

Forrás: Saját szerkesztés

Megkérdeztük az idős lakókat arról is, hogy mennyi ideje laknak az intézményben. Közülük 21,6\% (35 fö) kevesebb, mint egy éve él az intézményben. 24,7\% (40 fó) egy-két éve, 53,7\% (87 fő) pedig már több mint három éve lakik bent. A lakók közül 13,3\% (22 fó) egyedül lakik saját szobában. A többség, 71,5\% (118 fó) csoportosan lakik az intézményben más szobatársakkal együtt. Az idős válaszadók 13,9\%-a (23 fő) házastársával, 1,2\%-a (2 fő) pedig élettársával osztozik egy szobán.

\section{Az idősek szociális kapcsolatai}

Össztársadalmi érdek, hogy az időskorúak ne veszítsék el kapcsolataikat, ne szigetelődjenek el, hanem vegyenek részt közösségi tevékenységekben, legyenek viszonzott társas kapcsolataik, amelyek hatására a közösség hasznos tagjának érezhetik magukat. A generációk közötti együttműködés, kapcsolattartás erősítése több szempontból is fontos. Egyrészt segíti a generációk közötti tudástranszfer folyamatát, másrészt ezzel párhuzamosan a generációs feszültségek enyhítését, melynek hátterében leggyakrabban a különböző világnézet, eltérő tudás, más gondolkodásmód, nézőpont, különböző tapasztalatok, eltérő ismeretek és szókincs áll (Lampek 2015, Dobos 2016). A bentlakásos intézményben élő idősek körében a generációk közötti kapcsolatokon túl, melyben elsősorban a gyermekek és unokák érintettek, a saját generáción belüli viszonyok, valamint az intézményben dolgozó gondozókkal való kapcsolatok fontosságát kell kiemelni. A korábbi hazai kutatások azt mutatják, hogy az idősek életminőségének legfontosabb mutatói az egészség megléte, a családhoz tartozás, mások segítése (és segítség kapása másoktól), a szeretet, az emberi kapcsolatok jellemzői, beszélgetés másokkal, valamint a belső és külső békesség megléte (Tróznai - Kulmann 2003). Az idősek egészséggel összefüggő életminőségében védőfaktornak minősül a problémacentrikus megküzdés, a jövőre vonatkozó célok és a társas támogatás megléte. Rizikótényezőként kell tekinteni a depressziós és szo- 


\section{TANULMÁNY}

rongásos tünetekre, a diszfunkcionális attitűdökre, a női nemhez való tartozásra, a fájdalomtünetekre és a negatív életeseményekre (Füzesi - Boros 2015).

Mindezeket alapul véve felmértük, hogy az általunk vizsgált célcsoport milyen személyes társas támogató rendszerrel, szociális kapcsolatokkal rendelkezik. Ennek megismeréséhez feltártuk, hogy az idős válaszadók hogyan viszonyulnak egymáshoz, szobatársaikhoz, gondozóikhoz. Kíváncsiak voltunk arra is, kivel tudják megbeszélni a problémáikat, valamint hogy kik és milyen gyakran látogatják őket.

Vizsgálatunkban azt tapasztaltuk, hogy az idős lakók többségének (55,7\%, 93 fő) jó a kapcsolata az intézményben lakótársaival. 29,9\% (50 fő) nyilatkozott úgy, hogy elfogadható a viszonya általában a többi lakóval. Míg 9\% (15 fô) úgy nyilatkozott, hogy nagyon jó a kapcsolata a többi lakóval, addig 4,8\% (8 fó) mondta azt, hogy rossz a kapcsolata a többiekkel, 0,6\% (1 fö) pedig azt, hogy nagyon rossz ez a viszony (5. ábra).

Korábban láthattuk, hogy a lakók többségének van szobatársa, ezért azt is megkérdeztük az idősektől, hogy milyennek érzik a kapcsolatot a közvetlen szobatársaikkal. A válaszokból úgy tűnik, hogy a lakóknak a közvetlen szobatársaikkal jobb a kapcsolatuk, mint általában az intézmény többi lakójával. 29,3\% (43 fő) azt mondta, hogy nagyon jó; 43,5\% (64 fó) pedig azt nyilatkozta, hogy jó a kapcsolata a szobatársaival. Közömbös (elfogadható) választ adott 19,1\% (28 fő), míg 5,4\%-nak (8 főnek) rossz, 2,7\%-nak (4 fónek) pedig nagyon rossz a kapcsolata a szobatársaival (5. ábra).

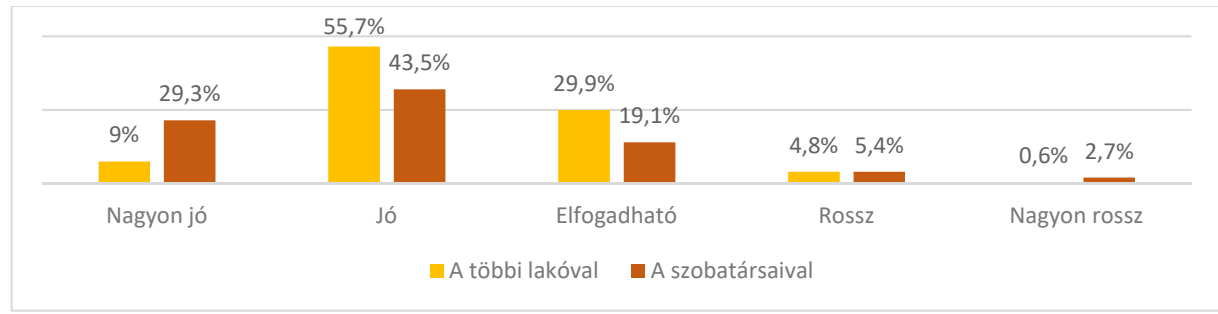

5. ábra. Milyen a kapcsolata általában az intézményben lakó társaival, a szobatársaival? Forrás: Saját szerkesztés

Ha az 1-től 5-ig terjedő Likert-skála átlagaival vizsgáljuk a lakótársakkal és a szobatársakkal való kapcsolatokat, akkor azt láthatjuk, hogy a lakótársakkal átlagosan 3,7 pontra, míg a szobatársakkal 3,9 pontra értékelték a válaszadók a viszonyukat.

A férfi és női lakók véleménye nem különbözik szignifikánsan azzal kapcsolatban, hogy hogyan vélekednek a lakótársakkal való kapcsolatukról. Mégis figyelemre méltó az az adat, hogy a nők valamelyest jobbnak ítélik meg a társaikkal való kapcsolatukat, mint a férfiak. A válaszadó nők közel háromnegyede, míg a férfiak közel fele vélte úgy, hogy jó vagy nagyon jó a kapcsolata az intézményben lakó társaikkal (1. táblázat). 


\section{TANULMÁNY}

1.táblázat. Milyen a kapcsolata általában az intézményben lakótársaival? (\%)

\begin{tabular}{|l|c|c|c|}
\hline & Férfi & Nő & Összesen \\
\hline Nagyon jó & 8,0 & 10,0 & 9,4 \\
\hline Jó & 48,0 & 59,1 & 55,6 \\
\hline Elfogadható & 34,0 & 27,3 & 29,4 \\
\hline Rossz & 8,0 & 3,6 & 5,0 \\
\hline Nagyon rossz & 2,0 & 0 & 0,6 \\
\hline
\end{tabular}

Forrás: Saját szerkesztés, $\mathrm{p} \leq 0,293$

Az intézmény lakóinak egymáshoz való viszonyulását egy további kérdéssel is vizsgáltuk. Itt azt az eredményt kaptuk, hogy az idős lakók 68,5\%-a (113 fó) úgy érzi, hogy a lakótársai befogadták. 57,3\% (94 fó) úgy nyilatkozott, hogy őt tiszteli a többi lakó, 45,7\% (75 fő) pedig azt mondta, hogy őt becsülik a többiek, további 44,2\%ban (73 főben) pedig megbíznak a többiek, úgy érzik a megkérdezettek. Ugyanakkor 15,2\% (25 fő) nyilatkozta azt, hogy a többi lakó távolságtartó vele szemben, 4,8\% (8 fő) azt, hogy őt lenézik a lakótársai, 4,3\% (7 fő) pedig úgy érzi, hogy kiközösíti őt az intézmény többi lakója.

A kapcsolataik jellegét, az egymáshoz való viszonyukat jól tükrözik azok az értékek, amelyeket megneveztek. A társadalomban az elfogadás, a pozitív megítélés jelzők, nevezetesen a becsülik, tisztelik, megbíznak benne, nem szoros viszonyokra utalnak, inkább mintha önmaguk minősítésére, csoporton belüli kiemelt szerepére mutatnának rá. A lenézés, a távolságtartás, a kiközösítés okáról nem beszélnek, amely lehet, hogy csak a bezárkózás okának szubjektív érzése, de lehet egészségi, vagyoni, műveltségbeli különbségből adódó tény is, de erre nem utaltak.

Továbblépve a lakótársak kapcsolatának elemzésében azt kértük a válaszadóktól, hogy az iskolai osztályzatokhoz hasonlóan értékeljék a felsorolt kijelentéseket ( 1 = egyáltalán nem jellemző, 5 = teljes mértékben jellemző). A felsoroltak közül a legmagasabb osztályzatot a befogadás, elfogadás kapta $(3,98)$. Ezt sorrendben követte a többi kijelentés a lakók egymás közötti kapcsolatáról: a kapcsolatokat a barátságosság $(3,90)$, türelem $(3,84)$, kölcsönös figyelem $(3,81)$, megértés $(3,65)$, bizalom $(3,53)$, nyitottság $(3,51)$ jellemzi. Az itt élő emberek megpróbálnak barátságot kötni egymással, szoros kapcsolatot $(3,40)$ és közös tevékenységet $(3,26)$ kialakítani. A bemutatott eredményekkel összecseng az idősek között kialakult baráti kapcsolatoknak a jellemzői. A lakók 50,9\%-a (83 fő) nyilatkozott úgy, hogy van olyan kapcsolata a lakótársaival az otthonban, amely mára baráti viszonnyá alakult. A megkérdezett lakók 41,7\%-a (68 fö) szerint nincs olyan ember a lakók között, akit a barátjának nevezne. 7,4\% (12 fô) pedig nem tudta eldönteni, hogy van-e barátja az otthonban. A nők valamivel többen (52,3\%) nyilatkoztak bent kötött barátságokról, mint a férfiak $(46,9 \%)$. 


\section{TANULMÁNY}

A bentlakásos intézmények lakóinak közérzetét nagyban befolyásolja, hogy milyen gyakran látogatják őket hozzátartozóik, rokonaik. Az egyszemélyes idős háztartásokban 2014-ben lebonyolított vizsgálat eredményei szerint az idősek 40\%-a heti rendszerességgel találkozik gyermekével (Patyán 2014). Saját vizsgálatunkban hasonló összefüggést találtunk. A lakók 36,9\%-a (59fö) válaszolta azt, hogy minden héten fogad látogatókat. 25\%-ukat (40 fót) havonta egyszer látogatnak meg. 11,9\%ukat (19 föt) évente néhányszor, 18,8\%-ukat (30 főt) pedig még ennél is ritkábban látogatnak meg az intézményben. Az idősek 7,4\%-a (12 fő) válaszolta azt, hogy őket soha nem látogatja meg senki.

Életkori bontásban azt látjuk, hogy a legidősebbek (71 év felettiek) látogatási gyakorisága kiemelkedik az ettől fiatalabbakéhoz képest (sig.p $\leq 0,014$ ). Közülük közel minden második lakót heti rendszerességgel, minden ötödik lakót pedig havi rendszerességgel látogatnak hozzátartozói. Ehhez képest a 48-60 éves korosztály tagjainak 16\%-a, a 61-71 évesek 21\%-a fogad minden héten látogatót, havonta pedig a 48-60 évesek 44,4\%-a, a 61-70 évesek 27,9\%-a. A legkevésbé látogatottak a 61-70 évesek. 42\%-ukat évente néhányszor, illetve nagyon ritkán látogatják. A másik két életkori csoport negyede számolt be hasonló látogatási mintázatról (2. táblázat).

2. táblázat. A válaszadó idősek látogatóik fogadásának gyakorisága életkor szerinti bontásban (\%)

\begin{tabular}{|l|c|c|c|c|c|c|}
\hline & Hetente & Havonta & $\begin{array}{c}\text { Évente } \\
\text { néhányszor }\end{array}$ & $\begin{array}{c}\text { Ennél is } \\
\text { ritkábban }\end{array}$ & Soha & Összesen \\
\hline 60 év alatti & 16,7 & 44,4 & 22,2 & 5,6 & 11,1 & 100 \\
\hline $61-70$ év közötti & 20,9 & 27,9 & 14,0 & 27,9 & 9,3 & 100 \\
\hline 71 éven felüli & 48,0 & 19,4 & 9,2 & 17,3 & 6,1 & 100 \\
\hline
\end{tabular}

Forrás: Saját szerkesztés, $\mathrm{p} \leq 0,014$

A látogatók az esetek 64\%-ában (103 fó) az idős emberek gyerekei. 25,8\%-ot (41 főt) a testvérei, 6,4\%-ot (10főt) pedig a korábbi szomszédjai látogatják. A lakók 25\%-a (40 fő) jelölte be az egyéb látogató kategóriát, amit csak feltételezhetünk, hogy legnagyobb számban unokákat és esetleg régebbi barátokat, barátnőket takarhat.

Statisztikailag meghatározó kapcsolatot találtunk a látogatási gyakoriság és a „Van-e Önnek gyermeke” kérdések között (sig.p $\leq 0,002$ ). A vártnak megfelelően azokat a bentlakó időseket látogatják heti rendszerességgel, akiknek van gyermeke. Körükben közel minden második idős embert látogatják minden héten (45,2\%), míg a gyermektelenek esetében ez az arány mindössze 6,5\%. Szomorú tényként nyugtázzuk azonban, hogy a gyermekkel rendelkező idősek közül minden harmadikat éven- 


\section{TANULMÁNY}

te néhányszor, nagyon ritkán, vagy sohasem látogatnak. Ilyen típusú látogatás (vagy annak hiánya) jellemző a teljes minta (gyermekesek és gyermektelenek) 38,1\%-ára. Mindez azt mutatja, hogy az idősek egy jelentős részének a lakótársakon és a gondozókon kívül ritkán van személyes kontaktusa másokkal. Ezért nagyon fontos, hogy a lakók és a gondozók között milyen bizalmi kapcsolat alakult ki (3. táblázat).

3. táblázat. A válaszadó idősek látogatóik fogadásának gyakorisága annak összefüggésében, hogy van-e gyermeke (\%)

\begin{tabular}{|l|c|c|c|c|c|c|}
\hline & Hetente & Havonta & $\begin{array}{c}\text { Évente } \\
\text { néhányszor }\end{array}$ & $\begin{array}{c}\text { Ennél is } \\
\text { ritkábban }\end{array}$ & Soha & Összesen \\
\hline Van gyermeke & 45,2 & 22,2 & 11,1 & 15,9 & 5,6 & 100 \\
\hline Nincs gyermeke & 6,5 & 32,3 & 16,1 & 29,0 & 16,1 & 100 \\
\hline
\end{tabular}

Forrás: Saját szerkesztés, $\mathrm{p} \leq 0,002$

Az idős lakók többségének (56\%, 93 fő) jó a kapcsolata az intézmény gondozóival. 24,7\% (41 fó) úgy véli, hogy nagyon jó viszonyt ápol velük. Míg 16,3\% (27 fô) úgy nyilatkozott, hogy elfogadható a kapcsolata a gondozókkal, addig 3\% (5 fó) mondta azt, hogy rossz a kapcsolata velük. Ha az 1-5-ig terjedő Likert-skála átlagértékét vizsgáljuk, akkor megállapítható, hogy a válaszadók 4,02 pontra értékelték az intézmény gondozottjaival való kapcsolatukat, ami jónak mondható.

Egy további kérdéssel is vizsgáltuk azt, hogy hogyan érzik az idős lakók, a gondozók hogyan viszonyulnak hozzájuk. Itt azt az eredményt kaptuk, hogy a lakók 73,5\%-a (122 fő) úgy érzi, hogy az intézmény dolgozói befogadták őket. 66,9\% (111 fó) úgy nyilatkozott, hogy tisztelik őt a gondozók, 59,5\% (99 fő) pedig azt mondta, hogy becsülik, további 44,3\% (74 fö) pedig úgy érzi, hogy szeretik a gondozók. Ugyanakkor 10,8\% (18 fô) nyilatkozta azt, hogy az intézmény dolgozói távolságtartóak vele szemben, 3,6\% (6 fő) azt, hogy lenézik a gondozók, 8,4\% (14 fó) pedig úgy érzi, hogy közömbös számukra. Látható az eredményekből, hogy az idős lakók kicsivel jobbnak ítélik meg a viszonyukat az intézmény dolgozóival, mint az intézmény többi lakójával.

Az idős lakók az esetleges problémáikat elmondani, azokat megbeszélni leginkább a dolgozókkal, ápolókkal (52,8\%, 86 fô) és a családtagokkal (49,4\%, 80 fő) tudják. Furcsának tűnhet, hogy a rangsor elején a dolgozók és az ápolók vannak, de alapvetően ők azok, akikkel fizikailag nap mint nap találkoznak. A szobatársaival a lakók 30,9\%-a (50 fő), a vezetővel 22,4\%-a (36 fô), a lakótársakkal pedig 20,2\%-a (33 fô) tud beszélni a problémáiról. A válaszadók 9,3\%-a (15 fő) mondta azt, hogy egy baráttal tudja ezeket megbeszélni. 6,7\% (11 fô) választotta az egyéb kategóriát, akik közül 9 lakó senkinek sem tudja elmondani a problémáit. 


\section{TANULMÁNY}

\section{Szabadidős tevékenységek}

A következőkben a bentlakásos idősotthonok lakóinak szabadidő-eltöltésére vonatkozó eredményeinket mutatjuk be. Meg kell említenünk, hogy ebben a speciális helyzetben az egyéni, de még inkább a társas szabadidő eltöltésének biztosításában, megszervezésében jelentős szerep hárul az adott intézményre. Ezért megkérdeztük az időseket arról, hogy az intézmény szokott-e kulturális, szabadidős rendezvényeket szervezni a lakók számára. A válaszadók 83,3\%-a (135fő) mondta azt, hogy igen, szokott. További 9,3\% (15 fó) válaszolta azt, hogy igen szokott, de nem eleget. Így összesen a lakók 92,6\%-a (150 fő) nyilatkozott úgy, hogy szokott az intézmény rendezvényeket szervezni a gondozottaknak. 5,4\% (9 fó) azt válaszolta, hogy nem szoktak ilyen rendezvények lenni, további 1,8\% (3 fő) pedig nem válaszolt a kérdésre.

Arra is kíváncsiak voltunk, hogy amennyiben vannak ilyen rendezvények, úgy részt vesz-e azokon a megkérdezett idős lakó. 36,2\% (59fô) rendszeresen részt vesz a rendezvényeken, és további 36,2\% (59 fő) pedig esetenként jelenik meg ezeken az alkalmakon. Tehát az idős lakók 72,4\%-a (118fó) megjelenik az intézmény által szervezett kulturális, szabadidős rendezvényeken. 25,2\% (41 fó) válaszolta azt, hogy soha nem volt még ilyen eseményen, néhányan pedig nem válaszoltak erre a kérdésre (4 fö).

Az iskolai végzettség tekintetében nem találtunk szignifikáns különbséget a magasabban és alacsonyabban iskolázott válaszadók véleménye között abban a tekintetben, hogy milyen rendszerességgel vesznek részt az intézményi programokon.

A nemi különbségek alapján láthatjuk, hogy a nők szívesebben járnak az intézmény által szervezett eseményekre ( $\mathrm{p} \leq 0,002$ ). 42,7\%-uk rendszeresen, 38,3\%-uk esetenként ugyan, de részt vesz ezeken a programokon, s 16,4\%-uk monda azt, hogy egyszer sem volt még ilyen rendezvényen. Ezzel szemben a férfiak legnagyobb része még soha nem vett részt ilyen programokon 41,7\%-uk (20 fö), 33,3\%-uk esetenként ellátogat (16 fó) és 22,9\%-uk (11 fö) mondta azt, hogy rendszeresen jelen van az előadásokon (4. táblázat).

4. táblázat. Ön részt szokott venni az intézmény által szervezett rendezvényeken? (\%)

\begin{tabular}{|l|c|c|c|c|}
\hline & $\begin{array}{c}\text { Igen, } \\
\text { rendszeresen }\end{array}$ & $\begin{array}{c}\text { Igen, } \\
\text { esetenként }\end{array}$ & Nem, soha & Nem tudja \\
\hline Férfiak & 22,9 & 33,3 & 41,7 & 2,1 \\
\hline Nők & 42,7 & 38,2 & 16,4 & 2,7 \\
\hline Összesen & 36,2 & 36,2 & 25,2 & 2,4 \\
\hline
\end{tabular}

Forrás: Saját szerkesztés, $\mathrm{p} \leq 0,002$ 


\section{TANULMÁNY}

Kíváncsiak voltunk, hogy a lakók egynegyede miért nem vesz részt ezeken a rendezvényeken, mi ennek az oka. A legtöbben egészségügyi okok miatt maradnak távol (betegségek, nehézkes mozgás). Ôk teszik ki a rendezvényekről távol maradók 35\%-át (14 fő). További 33,3\% (13 fő) nem érzi jól magát ebben a társaságban, 17,5\% pedig kedvetlenségre, érdektelenségre hivatkozva marad távol a rendezvényektől. Néhány idős lakó hivatkozott még lustaságra, a rossz tapasztalataira az ilyen rendezvényekről, és arra, hogy nincs ideje.

A szervezett programokat látogatóktól azt kértük, hogy értékeljék azokat az általunk megadott szempontok szerint az iskolai osztályzatokhoz hasonló módon. A lakók átlagosan négyes osztályzatot adtak az intézmény által szervezett szabadidős tevékenységekre. A legmagasabb értékelést a rendezvények szervezettségére $(4,17)$ adták az idős lakók. A második legjobb a rendezvények változatosságának $(4,12)$ az értékelése volt. Ezt követte sorrendben a többi kijelentés: jól érzem magam a rendezvényeken (4,04), az ellátás jól szervezett a programok alatt $(4,01)$, elég gyakran vannak ilyen programok $(3,98)$ és jó közösségépítöek ezek a programok $(3,82)$.

Az előadásokkal való elégedettséget is megvizsgáltuk nemi bontásban. Látható, hogy a nők minden tényezővel elégedettebbek voltak, mint a férfiak. Ők ezeket jellemzően 4-nek, azaz jónak értékelték, a férfiak inkább 3-as, azaz közepes minősítést adtak. Míg a nők legfontosabbnak azt tartják, hogy jól szervezettek legyenek a programok $(4,44)$, a férfiak számára a programok változatossága a fontos $(3,7)$. A nők legkevésbé fontosnak azt tartják, hogy jó közösségépítőek legyenek ezek az alkalmak (3,33), a férfiak pedig azt, hogy jól érezzék magukat (3,31) (5. táblázat).

5. táblázat. Értékelje 1-5-ig, hogy mennyire elégedett a szabadidős tevékenységekkel? (átlag)

\begin{tabular}{|l|c|c|c|c|c|c|}
\hline Neme & $\begin{array}{c}\text { Jól érzem } \\
\text { magam } \\
\text { ezeken a } \\
\text { rendezvé- } \\
\text { nyeken }\end{array}$ & $\begin{array}{c}\text { Elég gyakran } \\
\text { vannak } \\
\text { ilyen ren- } \\
\text { dezvények }\end{array}$ & $\begin{array}{c}\text { Jól szerve- } \\
\text { zettek ezek a } \\
\text { szabadidós } \\
\text { tevékenységek }\end{array}$ & $\begin{array}{c}\text { változatos } \\
\text { progra- } \\
\text { mokat } \\
\text { szerveznek }\end{array}$ & $\begin{array}{c}\text { Jó közös- } \\
\text { ségépítóek } \\
\text { ezek a } \\
\text { programok }\end{array}$ & $\begin{array}{c}\text { Az ellátás } \\
\text { jól szervezett } \\
\text { a programok } \\
\text { alatt }\end{array}$ \\
\hline Férfi & 3,31 & 3,67 & 3,56 & 3,70 & 3,33 & 3,68 \\
\hline Nő & 4,38 & 4,12 & 4,44 & 4,31 & 4,01 & 4,17 \\
\hline Anova & $\mathbf{0 , 0 0 0}$ & 0,078 & $\mathbf{0 , 0 0 0}$ & $\mathbf{0 , 0 2 2}$ & $\mathbf{0 , 0 1 7}$ & $\mathbf{0 , 0 4 7}$ \\
\hline
\end{tabular}

Forrás: Saját szerkesztés

Az előadásokkal való elégedettséget a válaszadók iskolázottságának függvényében is megvizsgáltuk, azonban statisztikai különbséget nem találtunk a megszerzett iskolázottsági fokozat és a válaszadók véleményének tükrében. Úgy tűnik tehát, hogy hasonlóan vélekednek a különböző iskolázottságú lakók az előadásokkal kapcsolatban. 


\section{TANULMÁNY}

Az intézmény szolgáltatásfejlesztésének egyik eleme a lakók szabadidő-eltöltésének javítására, valamint az időskori tájékoztatásra, tanulásra kívánt reflektálni, ezért megkérdeztük az időseket, hogy szeretnék-e, ha az intézmény előadásokat szervezne számukra. A többség (64,8\%, 105 fó) pozitívan nyilatkozott az előadásokat illetően, és szeretné, ha a fenntartó szervezne ilyen típusú programokat. Minden ötödik válaszadó $(20,4 \%, 33$ fó) mondta azt, hogy nem tartja fontosnak ezeket. További 14,8\% (24 fó) pedig bizonytalan választ adott a kérdést illetően.

A nők szignifikánsan pozitívabban nyilatkoztak arról, hogy az intézmény szervezzen-e előadásokat a gondozottak számára. Közel háromnegyedük (81 fó) szeretné, ha lennének ilyen előadások, míg a férfiaknak csak a 45,8\% (22 fó) válaszolt hasonlóan. Ezzel párhuzamosan míg a nőknek csak a 12,8\%-a (14 fő) nem szeretne ilyen rendezvényeket, addig a férfiak 33,3\%-a adott nemleges választ. Bizonytalan a kérdést illetően a nők 12,8\%-a (14 fő), a férfiaknak pedig 20,8\%-a (10 fő) (6. táblázat).

6. táblázat. Szeretné, hogy az intézmény előadásokat szervezzen a gondozottaknak? (\%)

\begin{tabular}{|l|c|c|c|}
\hline & Igen & Nem & Nem tudja \\
\hline Férfi & 45,8 & 33,3 & 20,8 \\
\hline Nő & 74,3 & 12,8 & 12,8 \\
\hline
\end{tabular}

Forrás: Saját szerkesztés, $\mathrm{p} \leq 0,002$

A magasabban és az alacsonyabban iskolázott lakók válaszai között nem találtunk statisztikai különbséget a tekintetben, hogy szeretnék-e, hogy az intézmény előadásokat szervezzen.

Az idős lakók részvételi szándéka is érdekelt minket. 29,2\% (42fó) biztosan ott lenne, 47,9\% (69 fö) pedig témától függően venne részt ilyen előadásokon. 13,9\% (20 fö) nyilatkozott úgy, hogy nem valószínű, hogy érdeklődne az előadások iránt, 9\% (13 fó) pedig még nem tudja, hogy részt venne-e.

Látható, hogy az érdeklődő lakók közel fele abban az esetben venne részt ezeken az előadásokon, ha a téma elnyerné a tetszését. Az igényfelmérés szellemében a következő kérdésnél előadás témajavaslatokat vártunk a gondozottaktól. A válaszadók több mint fele (55,6\%, 65 fö) javasolta, hogy egészséges életmóddal, egészségmegőrzéssel kapcsolatos előadások legyenek. A válaszadók több mint harmada (34,2\%, 40 fó) hallgatna szívesen pszichológiai tartalmú előadásokat, (24,1\%, 28 fó) a generációk közötti különbségekről, (23,9\%, 28 fő) a generációk közötti kapcsolattartásról szeretne több információkhoz jutni. Ezt követte sorrendben a többi témajavaslat: a lelki egészségvédelem $(21,6 \%, 25$ fó), a szépkorúak társas kapcsolatai $(17,9 \%$, 21 fö), az időskori depresszió (17,9\%, 21 fô), a mentális állapot védelme, megőrzése $(17,9 \%, 21$ fó), a gyászfeldolgozás (14,5\%, 17 fö) és az időskori intimitás (8,5\%, 


\section{TANULMÁNY}

10 fö). Az egyéb kategóriát további 8,5\% (10 fő) jelölte be, melyhez kapcsolódóan a következő javaslatok születtek: természetvédelem, kultúra, Ki mit tud? vetélkedő, zene, színház, humor, ének, film és sport. Utóbbi tekintetében természetesen egy kíméletes, az életkori és fizikális sajátosságoknak megfelelő sportolási módot, például az intenzív sétát érdemes kiemelni, vagy ahogyan arra Móré és Bene (2020) utal, akár - megfelelő infrastrukturális feltételek mellett - az online sportolás lehetőségét.

Az előadások témáját illetően nem volt szignifikáns különbség a nők és a férfiak igényei között, továbbá jelentős korcsoportonkénti különbségeket sem fedeztünk fel. Az életkori csoportok menti összehasonlításban az időskori depresszió iránti érdeklődés mentén tártunk fel statisztikai különbségeket. Az időskori depresszió témaköre szignifikánsan jobban érdekli a 61-70 év közöttieket (34,8\%, 8 fó), mint a tőlük idősebbeket (11,8\%, 9 fó), vagy a fiatalabbakat (23,5\%, 4 fó).

7. táblázat. Milyen témában javasolna előadást korcsoport szerinti bontásban (\%)

\begin{tabular}{|l|c|c|c|c|}
\hline & $\begin{array}{c}\mathbf{6 0} \text { év } \\
\text { alattiak }\end{array}$ & $\begin{array}{c}\mathbf{6 1 - 7 0} \text { év } \\
\text { közötti }\end{array}$ & $\begin{array}{c}\mathbf{7 1} \text { éven } \\
\text { felüli }\end{array}$ & Szignifikancia \\
\hline Az időskori depresszió & 23,5 & 34,8 & 11,8 & 0,036 \\
\hline
\end{tabular}

Forrás: Saját szerkesztés

Az iskolázottság vonatkozásában két esetben mérvadóak a különbségek a különböző előadásokkal kapcsolatos érdeklődésekben. Egyrészt az időskor pszichológiája témájában, melyről elsősorban a szakiskolai szakképesítéssel rendelkező idősek érdeklődnek legnagyobb arányban, de magas az érdeklődés a főiskolai végzettségúek körében is. Érdekes eredmény, hogy az egyetemi diplomával rendelkezők körében nem volt olyan személy, aki érdeklődne a téma iránt, így nem jelenthető ki, hogy a felsőfokú végzettségűek körében nagyobb érdeklődés lenne kimutatható. A mentális állapot védelme téma iránt érdeklődők több mint fele érettségivel rendelkezik, több mint negyede pedig szakiskolai szakképesítéssel. A felsőfokú végzettségűek nem mutattak érdeklődést ezen téma iránt.

8. táblázat. Milyen témában javasolna előadást iskolai végzettség szerinti bontásban (\%)

\begin{tabular}{|l|c|c|c|c|c|c|c|}
\hline & $\begin{array}{c}\text { Kevesebb, } \\
\text { mint nyolc } \\
\text { általános }\end{array}$ & $\begin{array}{c}\text { Nyolc } \\
\text { általános }\end{array}$ & $\begin{array}{c}\text { Szakiskolai } \\
\text { szak- } \\
\text { képesítés }\end{array}$ & Érettségi & Fóiskola & Egyetem & $\begin{array}{c}\text { Szignifi- } \\
\text { kancia }\end{array}$ \\
\hline $\begin{array}{l}\text { Az időskor } \\
\text { pszichológiája }\end{array}$ & 15 & 13,5 & 45,2 & 23,1 & 30 & 0 & 0,034 \\
\hline $\begin{array}{l}\text { Mentális állapot } \\
\text { védelme }\end{array}$ & 5 & 8,1 & 31,3 & 53,8 & 0 & 0 & 0,000 \\
\hline
\end{tabular}

Forrás: Saját szerkesztés 


\section{TANULMÁNY}

Megkérdeztük azt is a gondozottaktól, hogy véleményük szerint milyen időtartamú előadások lennének ideálisak az idős lakóknak. 64,5\% (80 fő) nyilatkozott úgy, hogy a rövidebb előadásokat és a minél több témát preferálná. 14,5\% (18 fő) szerint egy-két előadás lenne a jó, azonos témában. 12,1\% (15 fő) szerint viszont előadássorozatok indítása lenne a legideálisabb egy adott témában. 8,9\% (11 fő) jelölte be az egyéb kategóriát, ahol jellemzően a félórás és az egyórás időtartamú előadásokra érkeztek javaslatok.

\section{Összegzés}

Elemző munkánkban a bentlakásos idősotthonban élők szociális kapcsolatait, szabadidő-eltöltését tártuk fel. Kiemelten kezeltük az érintettek időskori tanulását, informálódást segítő témák tartalmára tett javaslatainak bemutatását. Felmérésünk célja az volt, hogy mindazon túl, hogy megismertük az idősek helyzetét, eredményeink alapjául szolgáljanak egy későbbi szolgáltatásfejlesztési terv kidolgozásához. Úgy véljük, hogy a lakók igényeihez mért fejlesztés hosszútávon hozzájárul az idősek fizikai és mentális egészségének megőrzéséhez, életminőségének javításához.

Eredményeink alapján megállapíthatjuk, hogy az általunk vizsgált idősek nem alkotnak egységes csoportot. Szociális kapcsolataikban, nyitottságukban, közösségi tevékenységekben való részvételükben, érdeklődési körükben differenciák figyelhetőek meg, melynek elsősorban egészségügyi, szociális, életkori okai vannak.

Az idős lakók többsége jó kapcsolatot ápol lakótársaival, s az intézmény dolgozóival, a gondozókkal való kapcsolatuk minősége is kedvező képet mutat. A mindennapi életvitelük, egészségi állapotuk fontos része a hozzátartozókkal való kapcsolattartás, de a napi szükségleteik, problémáik már inkább a gondozókhoz, a belső munkatársakhoz kapcsolják őket. Problémáikat az esetek többségében a gondozókkal és a családtagokkal beszélik meg. A megkérdezettek a saját önértékelésük fontos részének tekintik azt, hogy milyen a viszonyuk a többiekkel (tisztelik, becsülik stb.).

Az intézmény által szervezett szabadidős programokon általában megjelennek a lakók, de magasabb részvételi arány prognosztizálható, ha az érdeklődésükhöz közelebb álló témákban, az életkori sajátosságaiknak megfelelő időtartamban szerveződnének ezek a programok. A hitéleti tevékenységben valamennyien részt vesznek. Mindemellett sokan preferálták az egészséges életmóddal, egészségmegőrzéssel, a konfliktuskezeléssel, az időskor pszichológiájával és a generációk közötti különbségekkel, együttműködéssel kapcsolatos előadások szervezését. 


\section{TANULMÁNY}

\section{Irodalom}

Bagdy E. (2000): Fejlődéslélektan az életfolyamaton át. Pszichoterápia, 9(10): 263296.

Berkman, L. F., Syme S. L. (1979): Social networks, host resistance, and mortality: A nine year follow-up study of Alameda County residents. American Journal of Epidemiology, 109(2): 186-204.

Cohen-Mansfield, J. - Marx, MS. - Thein, K. - Dakheel-Ali - M. (2009): The impact of past and present preferences on stimulus engagement in nursing home residents with dementia. Aging \& Mental Health, 14(1): 67-73. doi: 10.1080/13607860902845574.

Dobos Cs. (2016): Generációk közötti kommunikáció és tudástranszfer sajátosságai. Alkalmazott Nyelvészeti Közlemények, Miskolc, XI. évfolyam, 1. szám, 29-39.

Donászy M. (2002): Időskori szerepek és krízishelyzetek. In: Tariska P. (szerk.): Kortünet vagy kórtünet. Mentális zavarok az időskorban. Medicina Könyvkiadó, Budapest. 46-56.

Ellwardt, L. - Peter, S. - Präg, P. - Steverink, N. (2014): Social Contacts of Older People in 27 European Countries: The Role of Welfare Spending and Economic Inequality. European Sociological Review, Vol. 30 No. 4, 413-430.

Füzesi Zs. - Boros J. (2015): Idősek életminősége és egészségmagatartása. In: Lampek K. - Rétsági E. (szerk.): Egészséges idősödés. Pécsi Tudományegyetem, Egészségtudományi Kar, Pécs, 8-26.

Hézser G. (2002): A pásztori pszichológia gyakorlati kézikönyve. Magyarországi Református Egyház Kálvin János Kiadója, Budapest

Huszti É. - Ember Zs. (2019): Társas kapcsolatok és mentális egészség szegregált településrészeken. Egészségfejlesztés, 60(5): 36-45.

Iván L. (2002): Az öregedés aktuális kérdései. Magyar Tudomány, 108. évf. 4. szám, 412-418.

Janke, M. C. - Nimrod, G. - Kleiber, D. A. (2008): Leisure activity and depressive symptoms of widowed and married women in later life. Journal of Leisure Research, 40(2): 250-266.

Jeszenszky Z. (2003): Az időskori mentálhigiéné társadalmi jelentősége. In: Kovács M. (szerk.): Időskori depresszió és szorongás. Springer, Budapest, 23-29.

Kopp M. - Skrabski Á. (2007): Magyar lelkiállapot az ezredforduló után. Távlatok, www.tavlatok.hu/86/86kopp_skrabski.pdf (Utolsó letöltés: 2020. 05. 15.)

KSH - Népesség, népmozgalom (1941-). http://www.ksh.hu/docs/hun/xstadat/ xstadat_eves/i_wnt001c.html (Utolsó letöltés: 2021. 01.17.) 


\section{TANULMÁNY}

Lampek K. (2015): Az aktív idősödés és a társadalom. In: Lampek K. - Rétsági E. (szerk.): Egészséges idősödés. Pécsi Tudományegyetem, Egészségtudományi Kar, Pécs 28-46.

Monostori J. - Gresits G. (2018): Idősödés. In: Monostori J. - Őri P. - Spéder Zs. (szerk.): Demográfiai Portré 2018. KSH Népességtudományi Kutatóintézet, Budapest, 127-145.

Móré M. - Bene Á. (2020): Karanténsport - A testmozgás jelentősége időskorban. Magyar Gerontológia, 12. (Különszám), 44-45. https://doi.org/10.47225/ MG/12/Különszám/8475. (Utolsó letöltés: 2021. 01. 15.)

Patyán L. (2014): Egyszemélyes háztartásban élő idősek életminősége. Acta Medicinea et Sociologica, 5. évf. 12-13. szám, 123-141.

Pikó B. (2007): Egyenlőtlenségek vizsgálata a serdülők és az idősek egészségi állapotában mint szociológiai kihívás. Szociológiai Szemle, 17. évf. 1-2. szám, 99-109.

Preston, S. H. (1984): Children and the Elderly, Divergent Paths for America's Dependents. Demography, 21. évf. 4. szám, 435-458.

Szalkóné Bodnár T. (2020): A magyar idősgondozás jövője a humán erőforrás tükrében. Szakdolgozat, Debreceni Egyetem Egészségügyi Kar, Nyíregyháza

Törőcsik M. (2015): Az idősek társas kapcsolatai. In: Lampek K. - Rétsági E. (szerk.): Egészséges idősödés. Pécsi Tudományegyetem, Egészségtudományi Kar, Pécs, 120-141.

Tróznai T. - Kullmann L. (2003): Életkor és életminőség. In: Kovács M. E. (szerk.): Időskori depresszió és szorongás. Springer Tudományos Kiadó, Budapest 